\title{
Should Shadow Education Stay as a Shadow or Exist as Co-curricula Alongside Mainstream Education?
}

\author{
Yvonne Wei (Corresponding author) \\ Department of Educational Administration and Leadership, Assumption University \\ 3593 Soi Ramkhamhaeng 24 Hua Mak, Bangkapi District, Bangkok 10240, Thailand \\ Tel: 66-81-372-0522Ｅ-mail:wei.yvonne@gmail.com
}

\begin{abstract}
Wenyu Guan
Department of Foreign Language, Guangdong Medical University

XinCheng Road 1, Songshan Lake, Dongguan, Guangdong Province, China
\end{abstract}

Tel: 86-152-2034-1870Ｅ-mail: guanwenyu.1234@qq.com

\author{
Received: February 28, 2021 Accepted: March 25, 2021 Published: April 5, 2021 \\ doi:10.5296/jei.v7i1.18368 URL: https://doi.org/10.5296/jei.v7i1.18368
}

\begin{abstract}
Intense competition and educational privatization have fostered demands for student personalization, leading to shadow education becoming entrenched in the Asian education sector. Its social influence is expanding and far-reaching, which has attracted many scholars to study this issue. Scholars have been arguing about the adverse effects of shadow education on widening the inequality of social problems, increasing students' psychological pressures, and also the moral conflicts that teachers face. This position paper explores and discusses the rationality of shadow education from three dimensions: social, psychological, and economic. It argues that shadow education should exist as a co-curricular or supplement to formal mainstream education because it serves as a mirror that can reflect the missing parts of formal education, as shadow education can assist lower academic performing students and cater to need-oriented functions under-utilized within mainstream education. This article concludes with some recommendations for education policymakers in the Thailand Ministry of Education (MOE) in Thailand regarding the rising of the shadow education phenomenon. With stronger oversight of shadow education operators, improved communication between mainstream schools and parents, and increased financial support to the public education sector, a dynamic synergy between mainstream schools, shadow education operators, parents
\end{abstract}


and students can be achieved.

Keywords: Shadow education, Mainstream education, Private tutoring, Ministry of Education (MOE), Government policies

\section{Introduction of Shadow Education}

Shadow education, also known as private tutoring or private supplementary tutoring, is commonly practiced in Asia, generating billions of dollars in revenue each year, and spreading across the globe at a remarkable speed (Bray \& Liu, 2016). Stevenson and Baker (1992) first advocated shadow education after an in-depth investigation into the remedial education of Japanese high school students; they described shadow education as a range of educational activities outside of the school to improve academic performance and opportunities to further education. The learning curriculum and content coverage that shadow education provides change accordingly to the associated mainstream schools. Shadow education is fee-based private supplementary tutoring (Mustary, 2019) with a flexible instructional design ranging from one-on-one tutoring to classroom instruction. According to Kim et al. (2018) shadow education exists in five forms which include: private tutoring institute; home-visit private tutoring; internet-based private tutoring; subscribed learning programs; and after-school programs. This informal education service of tutoring is delivered by mainstream teachers, college students, retired teachers, community members, or even university professors (Liu \& Bray, 2017). In 1999, Bray further defined the connotation of "shadow education", which includes two aspects. The first is that the subjects taught in shadow education are the same subjects taught in mainstream schools, which mainly refers to academic courses; the second refers to the tutoring services provided by enterprises or individuals that are for-profit based. Kim and Jung (2019) defined shadow education's curriculum as supplementary curriculum outside schooling, provided by educational enterprises with the primary goal to improve students' academic achievement in formal education. Shadow education provision focuses on three main components: individual achievement, personalized learning environments, and customized instructional strategies to fit students' learning needs or style. Buchmann et al. (2010) defined shadow education simply as educational activities, such as tutoring and extra classes, occurring outside the formal channels of the education system and designed to improve the students' chance of successfully moving through the formal educational process. In this paper, shadow education is defined as any form of tutoring outside of mainstream school hours with the extra supplementary curriculum that supports core subjects in formal education such as literacy, language, math, science, and history with a focus on the secondary education level or above. Thus, supplementary tutoring of individual interests such as arts, crafts, or sports and different education levels fall outside the scope of discussion.

Shadow education has become a widespread phenomenon worldwide. Traditionally, it has been prominent only in East Asia countries, such as Thailand, China, Japan, and Korea (Stevenson \& Baker, 1992) and in India (Baker \& Lykins, 2012). In Thailand, with the introduction of registered shadow education in 1969 , there was a $117 \%$ increase in registered institutions and a 52\% increase in student enrollment for these services between 2007-2013 
(Akaraphanth, 2015). In 2004, the proportion of students from elementary, middle, and high schools in mainland China who participated in private supplementary tutoring reached $74 \%$, $66 \%$, and 53\%, respectively (Xue \& Ding, 2009). Likewise, in South Korea, the percentage of private tutoring ranges from $83 \%$ in elementary and, $75 \%$ in middle to $56 \%$ in high school (Kwak, 2014). The figures from both China and South Korea indicate a high percentage of students attending private tutoring as early as elementary school. Japan is another country that showed students started tutoring at an early stage with the percentage of $24 \%$ of elementary school students and $60 \%$ of middle school students who have received private tutoring. Studies have shown that about $70 \%$ of students have received private tutoring before graduating from high school (Bray \& Liu, 2016). In India, Sen (2010) stated that 57\% of primary students in West Bengal were receiving private tutoring. Sujatha and Rani (2011) reported on a detailed survey of senior secondary students in four states: Andhra Pradesh, Kerala, Maharashtra, and Uttar Pradesh, showing that 58.8\% of Grade 10 students were receiving tutoring. Although the participation rate of private tutoring in Asia is generally higher, it is now more visible across the globe both in developed and developing countries. Bray et al. (2020) pointed out a list of cross-national indicators of the increasing trends of shadow education starting from the finding in Argentina that $92.4 \%$ of medical degree students who gained admission in reputable university had attended some form of private tutoring; 33\% of students in Canada have been enrolled in some forms of shadow education; Cambodia had close to $90 \%$ of students in secondary education level who have joined shadow education classes to support their studies; in London, $44 \%$ of the people questioned in the survey had at some point in time attended shadow education; and in a study in Ghana it was found that $48 \%$ out of 1020 households paid for additional tutoring fees during their children's primary level studies. In African, countries like Mauritius, and Kenya, the proportion of primary school students participating in private tutoring has reached more than 80\% (Kulpoo \& Soonarane, 2005; Onsomu et al., 2005). In France, more than half of the junior and senior high school students are receiving shadow education (Melto, 2007). In 2001, the expenditure level of private tutoring in Turkey almost caught up with that of mainstream education, by reaching $1.44 \%$, compared with $2 \%$ for mainstream education (Tansel $\&$ Bircan, 2006). Taken together, these studies indicated that shadow education has no boundaries, and yet is a service that is apparently used both in the high and low socio-economic status family.

Cultural is an additional factor of consideration. East Asian people are highly influenced by the values inherent in their Confucian heritage, by which they believe that success in education brings higher social status, better employment opportunities and higher standard of living (Bray \& Liu, 2016). In Thailand, competition for limited placements within prestigious education institutions such as Chulalongkorn University, Mahidol University, Thammasat University, Kasertsart University and Chiang Mai University contribute to the demand for shadow education among school systems (Lao, 2014). The percentage of those universities' enrollment of first-year undergraduates consists of only $4 \%$ of the total first-year undergraduates in Thailand. University acceptance requirements in Thailand are still heavily exam and secondary school grades focused. In comparison to other countries such as South Korea, Singapore, the USA, and Germany, besides grades from entrance exams and school grades, additional internship experiences, volunteering experiences, letter of 
recommendations from schoolteachers and personal essays are all enrollment requirement criteria (Akaraphanth, 2015). Competition is an ongoing process for students who must continuously excel in numerous admission exams and continue to perform successfully to retain positions in all levels of the educational system. The need to compete has created an awareness among students and parents that legitimizes for them the influence and impact of shadow education on formal education success. As a result, educators and scholars have mixed attitudes towards shadow education.

Arguments against shadow education claim that shadow education re-enforces measurement-driven exams on students and defeats the fundamental education philosophy of life-long knowledge-based learning; the existence of shadow education poses a threat to social justice; and it may become a mechanism to maintain and expand social inequality (Verdis, 2002; Murawska \& Putkiewicz, 2006; Smyth, 2009; Yang \& Duan, 2008). Contrary to the researchers who support this claim, there is research that supports shadow education as empirical evidence confirms that students who receive additional support respond with better academic performance (Bray, 2007; Dang, 2007; Hu et al., 2015; Song \& Xue, 2017; Kim \& Jung, 2019; Xue \& Fang, 2020).

This position paper argues that shadow education should exist as a co-curricular or supplement to formal mainstream education, because it serves as a mirror that can reflect the missing parts of formal education, such that shadow education can assist lower academic performing students and cater to need-oriented functions under provided within mainstream education.

\section{Dimensions of Shadow Education}

Over the years, shadow education has been criticized for the expansion of social inequality, the placement of additional psychological demands on students, and the enhancement of teachers' moral conflict. This paper will discuss the main reasons for supporting shadow education within social, psychological, and economic dimensions.

\subsection{Social Dimension}

Numerous sociologists and educational scholars have examined the problems of social inequality that shadow education potentially exasperates. Verdis (2002), Murawska and Putkiewicz (2006), and Smyth (2009) pointed out that the existence of shadow education will threaten social equality because shadow education is perceived negatively as a money-driven industry that defeats the purpose of free education for all. Education should not be short-sighted, looking at only students' academic achievement. Instead, educators must strive for the ultimate goal of developing knowledgeable students with self-critical thinking skills that will guide them toward integration into society. The shadow education curriculum offers a limited learning scope. It focuses on specific subjects or tailored preparation for national exams (Teo \& Koh, 2019). Formal education, under mainstream schools, teaches students more theoretical knowledge and the life-skills that they can apply in the future. For instance, these outcomes include developing social manners at an early stage, social integration skills in the school environment, critical thinking skills, leadership skills, and even multiculturalism 
to promote responsible global citizenship (Liu, 2013).

The theoretical concepts of formal education and its expected outcomes are sometimes far reached from reality. Competition is a driving force for the high demands of shadow education services. Many studies showed that private tutoring had positive impacts on students' overall academic achievements. Mustary's (2019) research explored shadow education and the impacts caused on students in Bangladesh. The results showed that $70 \%$ of the participants agreed that private tutoring had helped students perform better in school. Subedi (2018) studied the reasons and consequences of private tutoring perceived by secondary schoolteachers and students in a community school in Nepal. He found that students who attended private tutoring managed study time effectively, and are more focused on learning for exams. In Thailand, shadow education students declared an increase in competence or self-efficacy level, gained confidence toward subject matters and also a sense of pride in success over the understanding and achievements progress made (Jones \& Rhein, 2018).

In comparison to mainstream education's curriculum, shadow education's curriculum is narrower and provides specific objectives for teachers and students; therefore, parents, teachers, and students see the direct outcome that it delivers. According to the Thailand Ministry of Education, shadow educational institutions or private tutoring is under the control of the Office of Private Education (OPEC). There are two types of licenses applicable to private tutoring institutions: these are individual and corporate. Their main objectives include summarized and revised academic content from mainstream school curriculum; providing further knowledge; and recommending techniques for exams or skills to improve academic performances (Lao, 2014) or shortcut techniques (Charoenkul, 2018). Hallsen (2020) studied supplementary education in Sweden, finding that the government's promotion of traditional education cooperating with private tutoring helps to address the increasing achievement gaps between different identified groups of students. All the policies and collaborations among government, schools, and private tutoring serve certain common goals: increasing students' achievements and labor employment. The reason why higher academic achievement is crucial is that society is driven by competition, and it is more so among Asian countries. The cultural factor plays a significant factor in shaping the performance of shadow education. Bray (1999) noted that shadow education is common in countries that emphasize effort. Emphasizing effort refers to spending more time and energy in studies to achieve outstanding competitiveness in the academic level attained, as compared to students that do not enroll in shadow education. Many Asian countries, under the influence of traditional Confucianism, believe that "effort is the key to future success", as a result, families have a strong demand for private tutoring.

The relationship between employment and education in the labor market has led to more private tutoring services. If education and employment are closely linked, this will stimulate competition in education (Liu, 2013). Parents will invest more time, money, and energy in finding suitable private tutoring services to help their children to enroll into a competitive or prestigious school. Students with those advantageous opportunities have better chances to determine their future success in the labor market. Teo and Koh (2019), in their study among 
parents and students in Thailand, stated that parents preferred curricular focus that would prepare their children for the workplace and the real world outside the classroom. Parents want their children to be prepared and equipped with knowledge and skills to plan for success in their future careers. This fundamental concept is the invisible force that drives parents' and students' motivation for better academic performance. The number of early enrollments into pre-kindergarten programs and playgroups are surging. Playgroups are also a type of shadow education that brings children at the age of 1 to 3 together to play through some interactive games that teach and develop motor skills. Most parents are worried that their child will lose at the starting line. It is, of course, an individual family's right as a fundamental human right to invest in their children's education, out of love (Heyneman, 2011). If governments and private enterprises continue to emphasize education achievement in their recruitment and promotion policies, the demand for shadow education will continue to increase (Weng, 2017).

\subsection{Psychological Dimension}

Under the psychological dimension, this paper focuses on the well-being of the student. A common argument against shadow education is that students' mental stress is caused by pressure, fear, and anxiety (Bray et al., 2020). The additional lesson on top of mainstream education studies creates psychological burdens for students. Students are fatigued by the end of the day and overloaded with assignments, resulting in few personal and social development opportunities. Students must continually sacrifice sleep to meet the increased study demands (Javadi \& Kazemirad, 2020).

In fact, shadow education is said to reduce stress among students because it provides a precise target objective than mainstream education (Bray et al., 2018). Mainstream offers a broad curriculum, making it harder for teachers to focus on individual needs (Teo \& Koh, 2019). When students in a large classroom setting, fall behind in lesson, it is often that teachers cannot provide adequate attention to all students. Once students lose interest and become unmotivated to learn, mental stress accumulates. External and internal pressure create anxiety, often resulting in cumulative negativity that manifests into serious societal issues. Shadow education services are there to solve such mental distress. Even though stress occurs with long studying hours, students and parents will realize that their decision paid-off after seeing the actual outcome of school achievement. After long study hours, releasing mental stress could also be carried out through other methods such as holidays or quality family bonding times.

Asian countries are considered to follow a collectivist structure, more so than the United States (GLOBE, 2020). Conformity and obedience are two prominent characteristics among Asian students, they are generally shy by nature (Bray et al., 2018). When students are not confident with the subject, they fear to be called upon to answer in class due to the feeling of embarrassment and humiliation when they make mistakes. Making mistakes is seen as having negative connotations in Asian culture because it represents losing face when admitting mistakes. According to Kim and Nam (1998), face is a significant influence factor on human behavior in Asian societies, and is referred as a public image of oneself that delineated in terms of social approval. When an individual is confronted with the situation of 
embarrassment or shame feeling, he or she will carry out the dynamics of losing face in public.

Compared with relatively conservative mainstream schooling, shadow education is diverse, market-oriented and more finely divided in educational design. Since the inception of shadow education, many tutors, administrators, and families have regarded it as a free space for those seeking educational autonomy and alternative choices (Zhang \& Bray, 2020). Shadow education services help parents who lack the knowledge to teach when children approach them for assistance, and to reduce the anxiety of parents and students. Moreover, Thai parents believe that tutoring services are professionals in what they do and children would be in good hands with them after school as they help children with homework or review of exam preparation etc. (Charoenkul, 2018). Students who attend shadow educational services will eventually gain self-confidence in subjects that were once problematic for them. In a Thai case study, Saengboon (2019) stated that shadow education services helped increase students' overall confidence in school, improved their understanding of subjects, and yielded better results in tests.

Since shadow education is a fee-based service, aligning services with parents' satisfaction is necessary to survive. Parents and students have options to select private tutoring services of their choice. Quite often, the essence of a positive teacher-student relationship motivates the learning of a child. Many students value shadow education teachers more than those in public schools, believing that shadow education teachers are more understanding, more patient, and provide better guidance than schoolteachers (Kim \& Jung, 2019). In Thailand, the high-power distance due to Thai culture norm revealed that teachers are respected figures and are seen to be infallible, which made the student-teacher relationship somehow distanced so that students do not approach teachers for questions (Cortina et al., 2017). As such, low-performance students in mainstream schools are forced into a denigrated relationship with their schoolteachers. However, shadow educational institutions offered students an active and engaging learning environment and reinforced the positive student-teacher relationship in contrast to the adversarial interaction in mainstream. Students reported better communication and interaction among private tutors, which ease the tension of students approaching for assistance.

Brehm (2015) observed teacher-students' behavior in shadow classrooms in Cambodia, and noted that teachers appeared to have a friendly relationship with students attending their tutoring classes, which was very different from the rules and etiquette in mainstream schools that restrict the behavior of teachers and students. Studies in other countries, such as Egypt (Hartmann, 2013) and India (Gupta, 2019), have reached similar conclusions. In fact, the prevalence of shadow education reflects the inefficiency of mainstream schooling. From another perspective, then, these studies exposed the inadequacy of mainstream schooling in satisfying students' need for knowledge. Kim and Lee (2010) pointed that parents will supplement the flawed public school education system through shadow education. Dang's (2007) study indicated that as teachers' quality improves, the expenditure on shadow education will decrease significantly. 


\subsection{Economic Dimension}

The hidden curriculum is a currently controversial issue that has influenced educational curricula both positively and negatively. A hidden curriculum refers to the unwritten, unofficial, and often unintended lessons, values, behaviors, procedures, or norms that exists in the educational setting. Though such expectations are not explicitly stated, the hidden curriculum is the unspoken enforcement of certain behavioral patterns, professional standards, and social beliefs revolves within the social learning environment (Alsubaie, 2015). The hidden curriculum encompasses various factors on how it influences and affects the school, such as cultural expectations, cultural values, school structures, institutional rules and regulation, and teaching strategies. Abroampa (2020) proposed an interactive hidden curriculum model that revolves around administrators, teachers, and learners, indicating the two main hidden curriculum levels: macro environment and micro environment. Macro environment refers to the outdoor milieu beside the classroom (the school environment) and micro environment indicates the classroom setting. The model describes affective and non-cognitive elements as an interactive function and socialization process that follow both in the classroom and outside the classroom due to the way a school is structured. Thus, the skills, values, and attitudes that the learners develop could be either good or bad, destructive or constructive all depend on the total development of individual learner (Abroampa, 2020). It is relatively difficult to observe what is the hidden curriculum, therefore it is necessary to infer the characters of the hidden curriculum (Alsubia, 2015).

The idea that one can pay to influence student performance is simply dangerous. There is only a thin line between investment in learning and an investment in the result of learning. The encouragement to buy performance is an act of educational corruption (Heyneman, 2011). Teachers play an important role which has strong influence on students both directly and indirectly regarding the requirement of shadow education, simply because teachers encounter students on a daily basis and know the students' needs. Often teachers' attitudes and behaviors send invisible cues that purposely fit their benefits.

Studies from Bray et al. (2018), and Javadi and Kazemirad (2020) indicated that in Cambodia, the hidden curriculum implied by schoolteachers intentionally delivered incomplete class lessons during school time which indirectly pressured students to attend private tutoring services (offered by teachers themselves or related services) for their benefits.

Bray et al. (2018) argued that teachers clearly state that specific knowledge of subject-related strategies will be taught during private tutoring. Although studies have shown that the majority of teachers claim to treat tutored and non-tutored students equally, some teachers perceived tutored students to be smarter, more responsible, and more motivated as compared to non-tutored students. However, teachers who were paid to give extra lessons tend to be more patient and developed favoritism toward tutored students (Bray et al., 2018, 2020). Due to this hidden rule, parents in Thailand feel forced to pay for extra tutoring, which could result in a burden on household finances (Lao, 2014). With social pressure and cultural expectations increasing, sending children to shadow educational services is no longer an option. It becomes a must-go place for students if they want to keep up in class. In the study 
of perception and motivation of private tutoring services from Thai high school students by Jones and Rhein (2018), the result showed that students focused heavily on GPA as the leading indicators of academic success, which served as positive reinforcement for the private tutoring services and the willingness to continue using the services. Schools also fear that teachers who do extra tutoring will leak out exam questions in advance, which will cause inequality of achievements among students (Bray et al., 2018).

Understanding the reasons for deception is crucial to countering educational corruption in the hidden curriculum. One of the main reasons is the lack of substantial salaries for teachers in developing nations (except private or international schools). Though teachers are aware of regulations that prohibit teaching extra lessons outside school hours, the need for extra income to support their own family creates pressure to contravene these rules. Suryadarma et al. (2006) pointed out that the low wages and weak incentives for teachers in public schools have led teachers to push students to take private tutoring to increase their income. As a result, private tutoring became teacher-oriented rather than student-oriented (Bray, 1999). In Vietnam, although the government prohibits private tutoring independent of the school system, teachers often organize family tutoring to increase their income. Ha and Harpham (2005) conducted a survey targeting eight years old Vietnamese students; even with the prohibition from the government, the result showed that $46 \%$ of students participated in private tutoring. Back in 2010 in Thailand, Pumasaran conducted a study about Thai teachers and findings showed that low salary indirectly forced approximately $20-25 \%$ of Thai teachers in schools to hold multiple jobs such as tutoring classes or evening classes in order to subsist in an underpaid occupation (Pumasaran, 2010).

Other shadow education's economic implications are the strengthening of human capital and extensive employment through companies or other informal ways (Bray et al., 2020). The act of financially supporting family or children is a fundamental human right and family right. Rather than stating this as a negative impact of shadow education, this paper put forth as a social awareness issue for the government to be informed of and to find incentives to address this problem.

\section{Summary}

This paper has discussed the social, psychological, and economic dimensions of shadow education. With the narrower curriculum of shadow education, teachers can focus on their objectives, which positively impacts students' academic achievements. Students have a higher chance to enroll in better universities with higher academic achievements. Parents are willing to invest in their children's education, hoping to create a path toward a brighter future. Though mental stress might occur due to study hours, the moment of being able to understand the subjects taught in class will eventually improve students' self-confidence and motivate their learning. Shadow education services are crucial for parents who lack the knowledge to themselves assist their children with their assignments and subjects. The growth of the hidden curriculum demands an increased awareness that the government must strive to reduce disparities in the classroom. 


\section{Conclusion}

From the above points mentioned and discussed, this paper concludes that shadow education should co-exist with mainstream schools as effective and supportive supplementary provision, together creating a positive synergy that fulfills a complete education system for students, parents, and teachers. The underlining motives of both formal and shadow education are all about enhancing children's learning. For parents to wish for their children the best possible future is a natural tendency. The formal mainstream education curriculum serves its purpose of educating students to become knowledgeable to enrich global citizenship. The shadow education curriculum provides additional help for students, teachers, and parents to fill-in aspects found missing in formal education. There are numerous arguments stating positive and negative impacts of both types of education curriculum. However, there are no right or wrong ways to approach this issue, but the process of finding the best possible solution is the key for success. Every family comes from different socio-economic status, having different experiences, requirements, and ideologies that they value. Both formal and shadow education serve the same goal; therefore, rather than viewing each other as competitors, both should respect each other as allies in the process of education. Students, teachers, and parents are the direct participants in educational development, and schools are responsible for managing and fostering a good learning environment. Policymakers need to understand the growing shadow education phenomenon and act responsively through effective decisions that are backed by analytical data. Finally, no matter how well the policymakers, schools, teachers, and parents collaborate, improvements will not be there without individual students' own behavior, determination, and motivation.

\section{Discussion}

Shadow education has become a global education phenomenon, playing a vital role in the education system. In Asia, the current exam-oriented education system provides the ground for private tutoring, which in turn intensifies students' pressure on competitive exam performance. If policymakers of the Ministry of Education in Thailand ignore factors causing this rising phenomenon and simply rejects shadow education's value, the effect may be counterproductive. The existence of shadow education is not to replace mainstream education but to act as a supplement and auxiliary role to mainstream education. Students can take private tutoring in their spare time to absorb and master more effectively the knowledge learned in mainstream schools. Parents also expect the improvement of their children's academic performance through shadow education.

This section recommends a few suggestions for policymakers regarding shadow education. Formal and shadow are like a mirror effect of each other. With its long-standing history, mainstream education is definitely more important because it is the standard model upon which shadow education relies. Rather than position themselves as competitors, leaders and policymakers need to be aware of the cause-effect relationship of the two entities. Shadow education services are much more flexible than mainstream education; therefore, it is easier for them to adjust to societal demands. However, formal education should acknowledge the strengths of shadow education and strive to improve in the management of the combined 
curriculum.

First, the government should monitor shadow education with more constructive and transparent rules, similar to those in place for the formal education system. Even though an establishment is registered as a private business, the government should still have the right to intervene and oversee the teaching management when it comes to education. Policymakers should implement standardized evaluation and measurements for all shadow education services. The study in Sweden by Hallsen (2020) explains how to incorporate both shadow and mainstream education together. With government subsidies successfully improving the overall education system, policymakers can use this as a reference for cross-integration. With the right regulation implemented, shadow education can serve as a bridge of communication between mainstream education and parents. Together they can pay close attention to individual students' learning progress. In combating social inequality issues, the government can provide subsidies for lower-income families attending shadow education services or by providing tax deductions as is done in Sweden. The government can encourage and advocate these remedial institutions to provide public welfare education by reducing taxes on remedial educational groups, providing tuition waivers for students from low-income families. Scholarships can be offered to academically disadvantaged students who have made more remarkable academic progress; thus, achieving a situation in which the government, schools and society work together to promote equal educational outcomes in the compulsory education stage (Hu, et al., 2015).

Secondly, the government needs to urge mainstream schools to establish an effective home-school communication platform, to reduce the communication gap between school and parents, so that parents can make reasonable choices for private tutoring based on feedback. Every year, schools should also collect relevant data on tutoring, effectively analyze the effects of tutoring, and make an unbiased account of what extent private tutoring can help students improve students' academic performance. This will allow parents to see private tutoring more rationally in order to guide parents so as to make a reasonable investment, thereby reducing the possible adverse effects of uncontrolled participation in shadow education. The government should also publicize the concept that parents should strengthen communication with their children, not focusing all the attention on their children's performance, in order to reduce unnecessary stress and blindly following others and appropriately assessing their child's needs.

Finally, the government should increase funding for public education. The government should take the financial burden off the teacher by making sure salaries meet the average income level as compared to other industries. By reducing teachers' income gap, teachers can then focus on teaching professionally and nurturing students at all levels. The reason why parents choose off-campus tutoring institutions to improve students' academic performance depends to a large extent on the deficiencies of mainstream education. Moreover, teachers' welfare benefits and retirement security have a significant impact on their work; it is the lack of related bonus program that leads to the low enthusiasm of teachers in mainstream education. In recent years, China has introduced policies to ensure that teachers in compulsory education are paid no less than civil servants (Ministry of Education of the People's Republic of China, 


\section{Macrothink

2018). However, teachers' welfare bonuses in remote areas are provided much less than teachers in developed areas, resulting in a relative imbalance in the teaching profession. The weakening of teachers' enthusiasm is not conducive to improving the quality of teaching in schools and will also lead teacher attrition. Therefore, shadow education has become a passive choice for many parents. Ultimately, education policymakers should, from the educational level, explore how school education and shadow education learn from each other, learn from each other's strengths, and co-exist in harmony, to understand each's advantageous strengths and to co-exist in a structured positive manner.

\section{References}

Abroampa, W. K. (2020). The hidden curriculum and the development of latent skills: The praxis. Journal of Curriculum and Teaching, 9(2), 70. https://doi.org/10.5430/jct.v9n2p70

Akaraphanth, L. (2015). Tutoring schools growth opportunities and the impact of tax collection. SCB Economic Intelligence Center.

Alsubaie, M. A. (2015). Hidden curriculum as one of the current issues of curriculum. Journal of Education and Practice, 6(33). Retrieved from https://files.eric.ed.gov/ fulltext/EJ1083566.pdf

Bray, M. (1999). The shadow education system: Private tutoring and its implications for planners (Fundamentals of Educational Planning No. 61). UNESCO International Institute for Educational Planning (IIEP). Retrieved from http://unesdoc.unesco.org/images/0018/ 001802/180205e.pdf

Bray, M. (2007). Educational tuition and private education costs. Beijing Normal University Press, Beijing.

Bray, M., \& Liu, J. Y. (2016). Measurement problems in shadow education research: Challenges and difficulties faced by TIMSS and PISA. Educational Development Research, $36(2), 18-23$.

Bray, M., \& Lykins, C. (2011). Shadow education private supplementary tutoring and its implications for policy makers in Asia. Philippines.

Bray, M., Kobakhidza, M. N., \& Kwo, O. (2020). Shadow education in Myanmar: Private supplementary tutoring and its policy implications (CERC Monography Series in Comparative and International Education and Development No. 13). UNESCO Comparative Education Research Center.

Bray, M., Kobakhidze, M. N., Zhang, W., \& Liu, J. (2018). The hidden curriculum in a hidden marketplace: Relationships and values in Cambodia's shadow education system. Journal of Curriculum Studies, 50(8), 435-455. https://doi.org/10.1080/00220272.2018. 1461932

Brehm, W. (2015). Enacting educational spaces: A landscape of portrait of privatization in Cambodia. The University of Hong Kong. 
Buchmann, C., Condron, D. J., \& Roscihno, W. J. (2010). Shadow education: Theory, analysis and future directions. Social Reform, 89(2), 483-490. https://doi.org/10.1353/sof. 2010.0073

Charoenkul, N. (2018). Shadow Education. In G. W. Fry (Ed.), Education in Thailand: An old elephant in search of a new mahout (pp. 627-650). Springer. https://doi.org/10.1007/978-98110-7857-6_25

Cortina, K. S., Arel, A., \& Smith-Darden, J. P. (2017). School belonging in different cultures: The effects of individualism and power distance. Frontiers in Education, 2(56). https://doi.org/10.3389/feduc.2017.00056

Dang, H. A. (2007). The determinants and impact of private tutoring classes in Vietnam. Economics of Education Review, 26(6), 684-698. https://doi.org/10.1016/j.econedurev.2007. 10.003

GLOBE. (2020). An overview of the 2004 study: Understanding the relationship between national culture, societal effectiveness, and desirable leadership attributes. GLOBE 2020 Global Leadership and Organizational Behavior Effectiveness. Retrieved from https://globeproject.com/study_2004_2007\#data

Gupta, A. (2019). Teacher-entrepreneurialism: A case of teacher identity formation in neoliberalizing education space in contemporary India. Critical Studies in Education, 124. https://doi.org/10.1080/17508487.2019.1708765

Ha, T. T., \& Harpham, T. (2005). Primary education in Vietnam: Extra classes and outcomes. International Education Journal, 6(5), 626-634.

Hallsen, S. (2020). The rise of supplementary education in Sweden: Arguments, thoughts styles, and policy enactment. ECNU Review of Education, 1(18). http://doi.org/10.1177/ 2096531120952096

Hartmann, S. (2013). Education "home delivery" in Egypt tutoring and social stratification (pp. 57-75). The Netherlands: Sense. https://doi.org/10.1007/978-94-6209-237-2_4

Heyneman, S. P. (2011). Private tutoring and social cohesion. Peabody Journal of Education, 86, 183-188. http://doi.org/10.1080/0161956X.2011.561662

Hu, Y. M., Fan, W. F., \& Ding, W. L. (2015). Does shadow education aggravate inequality of educational outcomes? An empirical study on PISA 2012 Shanghai data. Peking University Education Review, 3, 29-46.

Javadi, Y., \& Kazemird, F. (2020). Worldwide shadow education epidemic and its move toward shadow curriculum. Journal of Language Teaching and Research, 11(2), 212-220. https://doi.org/10.17507/j1tr.1102.09

Jones, W. J., \& Rhein, D. L. (2018). Tutorial schools in Thailand: Perceptions and motivations of Thai High School students. FIRE: Forum of International Research in Education, 4(2), 66-83. https://doi.org/10.18275/fire201704021137 
Kim, J. Y., \& Nam, S. H. (1998). The concept and dynamics of face: Implications for organizational behaviors in Asia. Organization Science, 9(4), 522-532. https://doi.org/ 10.1287/orsc.9.4.522

Kim, S., \& Lee, J. H. (2010). Private tutoring and demand for education in South Korea. Economics Development and Cultural Change, 58(2), 259-296. https://doi.org/10.1086/ 648186

Kim, Y. C., \& Jung, J. H. (2019). Shadow Education as Worldwide Curriculum Studies. Palgrave Macmillan. https://doi.org/10.1007/978-3-030-03982-0

Kim, Y. C., Gough, N., \& Jung, J. H. (2018). Shadow education as an emerging focus in worldwide curriculum studies. Curriculum Matters, 14. https://doi.org/10.18296/cm.0027

Kulpoo, D., \& Soonarane, M. (2005). The SACMEQ II project in Mauritius: A study of the conditions of schooling and the quality of education. Harare, Zimbabwe: SACMEQ.

Kwak, B. S. (2014). Struggle against private lessons in Korean education context (pp. 21-23). 28th Annual Conference of the Pacific Circle Consortium, Hong Kong Institute of Education.

Lao, R. (2014). Analyzing the Thai state policy on private tutoring: The prevalence of the market discourse. Asia Pacific Journal of Education, 34(4), 476-491. https://doi.org/10.1080/ 02188791.2014 .960799

Liu, J., \& Bray, M. (2017) Understanding shadow education from the perspective of the economics of education. Handbook of Contemporary Education Economics. http://doi.org/ $10.4337 / 978185369070.00023$

Liu, Y. S. (2013). The four differences of English course in mainstream schools and shadow education. Chinese Language and Literature Journal: Foreign Language Education and Teaching, 1, 104-106.

Melto, L. (2007). Le marche $d u$ soutien scolaire. Paris: Percepta. Retrieved from http://www.xerfi.fr/etudes/7SME04.pdf

Ministry of Education of the People's Republic of China. (2018). 贯彻落实十九大精神: 切 实解决中小学教师队伍建设中的实际问题 [Compulsory education teachers' salaries are not lower than civil servants will become the focus of supervision next year]. Ministry of Education of the People's Republic of China.

Murawska, B., \& Putkieicz, E. (2006). Education in a hidden marketplace: Monitoring of private tutoring (pp. 257-277). New York: Open Society Institute.

Mustary, M. (2019). The shadow education system in Bangladesh: A blessing or a curse? Global Education in Practice Teaching, Researching, and Citizenship (BCES Conference Book Vol. 17). Bulgarian Comparative Education Society.

Onsomu, E., Nzomo, J., \& Obiero, C. (2005). The S SACMEQ II project in Mauritius: A study of the conditions of schooling and the quality of education. Harare, Zimbabwe: SACMEQ. 


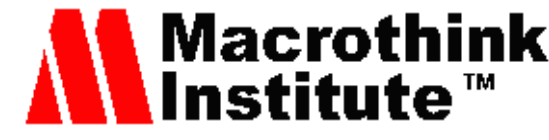

Pumsaran Tongliemna. (2010). Three Essays on Teacher Labor Markets in Thailand (p. 13). Retrieved from https://stacks.stanford.edu/file/druid:yw658sz0538/Pumsaran_Dissertation_ Aug2010_title_b-augmented.pdf

Saengboon, S. (2019). Shadow education in Thailand: A case study of Thai English tutors' perspective towards the role of private supplementary tutoring in improving English language skills. Learning Education and Acquisition Research Network Journal, 12(1), 38-54.

Sen, A. (2010). Primary Schooling in West Bengal. Prospects: Quarterly Review of Comparative Education, 40(3), 311-320. https://doi.org/10.1007/s11125-010-9164-4

Smyth, E. (2009). Buying your way into college? private tuition and the transition to higher education in Ireland. Oxford Review of Education, 35(1), 1-22. https://doi.org/10.1080/ 03054980801981426

Song, H. S., \& Xue, H. P. (2017). Extracurricular tutoring time, student achievements and social reproduction. Forum of Contemporary Education, 281(5), 51-62.

Stevenson, D. L., \& Baker, D. P. (1992). Shadow education and allocation in formal schooling: Transition to university in Japan. American Journal of Sociology, 97, 1639-1657. https://doi.org/10.1086/229942

Subedi, K. J. (2018). Shadow Education: A role of private tutoring in learning. International Journal of Humanities and Social Sciences, 1(2), 29-42.

Sujatha, K., \& Rani, P. G. (2011). Management of Secondary Education in India. New Delhi: Shipra and National University of Educational Planning and Administration.

Suryadarma, D., Suryahadi, A., Sumarto, S., \& Rogers, F. H. (2006). Improving student performance in public primary schools in developing countries: evidence from Indonesia. Education Economics, 14(4), 401-429. https://doi.org/10.1080/09645290600854110

Tansel, A., \& Bircan, F. (2006). Demand for education in Turkey: A Tobit analysis of private tutoring expenditures. Economics of Education Review, 25(3), 303-313. https://doi.org/ 10.1016/j.econedurev.2005.02.003

Teo, P., \& Koh, D. (2019). Shadow education in Singapore: A Deweyan perspective. Educational Philosophy and Theory, 52(8), 869-879. https://doi.org/10.1080/00131857. 2019.1700500

Verdis, A. (2002). School effectiveness research for educational evaluation in Greece. Institute of Education, University of London.

Weng, Q. Y. (2017). Review of research on "shadow education": Discussion on demand, effect, and equity. China Economics of Education Review, 2(2), 115-128.

Xue, H. P., \& Ding, X. J. (2009). A study on additional instruction for students in cities and towns in China. Education Research, 1, 39-46.

Xue, H. P., \& Fang, C. C. (2020). Does the competition for college entrance examination 


\section{Macrothink}

Journal of Educational Issues

ISSN 2377-2263

2021, Vol. 7, No. 1

affect extracurricular tutoring? An empirical analysis based on Chinese family panel studies. Peking University Education Review, 18(3), 172-192.

Yang, J. H., \& Duan, C. R. (2008). A comparative study of educational opportunities for migrant children, left-behind children and other children in rural areas. Population Research, $1,11-21$.

Zhang, W., \& Bray, M. (2020). Comparative Research on Shadow Education: Historical Developments and Future Directions. Journal of East China Normal University Educational Sciences, 11, 21-28.

\section{Copyright Disclaimer}

Copyright for this article is retained by the author(s), with first publication rights granted to the journal.

This is an open-access article distributed under the terms and conditions of the Creative Commons Attribution license (http://creativecommons.org/licenses/by/3.0/). 